\title{
EFFECT OF DIFFERENT DENTURE BASE MATERIALS ON NORMAL HUMAN FIBROBLAST CELL LINE: AN IN VITRO COMPARATIVE STUDY
}

\author{
Bassem Abdelhameed* and Hala Elkammar**
}

\begin{abstract}
PMMA is the most commonly used denture base material, however some concerns regarding its biocompatibility have been heavily studied over the years. ACETAL and PEEK are more recently introduced denture base material alternatives which are believed to be more biocompatible than PMMA.
\end{abstract}

Aim of the study: To evaluate and compare the short-term effects of PMMA, ACETAL and PEEK on human fibroblast cell line regarding cytotoxicity via direct contact. The assessment of cell cycle progression, cell death and ROS release were used as indicators.

Materials and methods: WI-38 cell line was divided equally into four groups. Group I was the control group, for groups II, III and IV the WI-38 cells were cultured with PMMA, ACETAL and PEEK, respectively. The groups were all assessed by flowcytometry for cell cycle and cell death evaluation and ELISA for determining ROS after 4 days of culturing.

Results: Pairwise analysis Bonferroni Method showed that highest mean values of total cell death, ROS levels and cell cycle arrest in the G2/M phase of the cell cycle was noted in group II (PMMA/WI38). Pearson's correlation test ( $\mathrm{r}$ test) showed that ROS levels correlated positively with total cell death and G2/M arrest. On the other hand, it correlated negatively with all the other parameters (G0/G1 and $\mathrm{S})$.

Conclusion: From the results of this study, we conclude that PEEK showed significantly superior biocompatibility compared to ACETAL and PMMA, enough to justify its use as a denture base material in spite of its high price.

KEYWORDS: PMMA, ACETAl, PEEK, Denture base, Cell cycle, Cytotoxicity, ROS.

* Lecturer, Department of Removable Prosthodontics, Faculty of Oral and Dental Medicine, Future University in Egypt, Cairo, Egypt .

** Associate professor of oral pathology, Faculty of Oral and Dental Medicine, Future University in Egypt, Cairo, Egypt . 


\section{INTRODUCTION}

For years the field of Removable Prosthetic rehabilitation in dentistry exhibited a substantial need to develop and improve materials and fabrication technologies owing to the undesirable health consequences associated with current materials ${ }^{(1)}$.

Polymethyle methacrylate (PMMA) is one the most notorious denture base materials used in dentistry. Inspite of having several desirable properties like its` ease of processing, affordability, light weight and esthetic properties PMMA is not perfect in every aspect ${ }^{(2,3)}$.

PMMA-based materials react in a complicated manner with the oral environment. In recent years, researchers have supported the idea that MMA monomers, by reacting with molecular oxygen may produce formaldehyde. Formaldehyde is categorised as a Group 1 carcinogen by"The International Agency for Research on Cancer" (IARC) also it is reported to cause severe allergic reactions ${ }^{(4)}$. In addition to the cellular stresses resulting from formaldehyde, there are the adverse effects caused bythe released or residual MMA itself, as well.

Recent findings suggest that these adverse effects revolve around the generation of reactive oxygen species and cellular oxidative stress. It has been revealed that on MMA exposure the cellular levels of glutathione (GSH), the natural free radical scavenger, is reduced while concomitantly ROS levels are elevated ${ }^{(5)}$. Consequently, liberated ROS react with cellular components, such as proteins, lipids, and even DNA, resulting in cell cycle arrest and eventually by apoptosis ${ }^{(6,7)}$.

At low doses, ROS has been linked to induction of cell survival responses, whereas prolonged exposure to ROS activates cell death processes like apoptosis, the key player in either scenario is P53 in the cell cycle check-points. P53 induces cell cycle arrest, DNA repair and senescence when cellular stress is low. However p53 down-regulates prosurvival proteins such as IAPs and Bcl-2 and upregulates pro-apoptotic proteins in case of a severe cellular stresses, favoring apoptosis ${ }^{(8)}$.
Cell cycle arrest in the G1-phase allows a chance for cells to either repair itself or "die" via the apoptotic pathway. Likewise, G2/M Cell cycle arrest indicates that the aberrations in the DNA are difficult to fix and repair ${ }^{(9,10)}$.

In spite of it being an affordable, and easily fabricated and cheap denture base material that has been the material of choice for decades, the short comings of PMMA ${ }^{(11)}$, prompted the use of thermoplastic materials, such as PMMA or ACETAL (AC) as an alternative. Some studies though put forward biocompatibility/cytotoxicty concerns as polyoxymethylene or AC is derived from formaldehyde, which might cause detrimental effects on the health of the oral tissues ${ }^{(12)}$. Furthermore, AC also imparts perfect esthetics, comfort and its flexibility allow it to adapt intimately to the constantly moving oral environment $^{(8)}$.

By the dawning of the twentieth century, a novel polymer molecule unraveled, poly (oxy-1,4-phenylene-oxy 1,4-phenylenecarbonyl-1,4-phenylene) commonly referred to as Poly Ether Ether Ketone(PEEK). It has been considered as an alternative to metallic appliances in trauma cases and orthopaedics ${ }^{(13)}$. No matter how deep scientists studied PEEK, it became clear that the one problem PEEK has is its price tag. It is a material with close to perfect physical, mechanical and biological properties. PEEK is a surprisingly inert material that is nonallergic to oral tissues, possess low plaque affinity, is resistant to hydrolysis and is resistant to most substances apart from concentrated sulfuric acid. PEEK's tensile strength and elasticity modulus are close to human bone, enamel and dentin ${ }^{(14,15)}$.

Cytotoxicity test is one of the biological screening and evaluation methods that use cell lines (in vitro) to observe changes in cell growth and reproduction caused by medical devices. Three types of cytotoxicity tests are described in the "International Organization for Standardization 109993-5": Extract, direct contact, and indirect contact tests ${ }^{(16)}$. 
To this end, this study was performed to evaluate and compare the short-term effects of PMMA, ACETAL and PEEK on human fibroblast cell line regarding cytotoxicity via direct contact tests. The assessment of cytotoxicity of these materials was done through evaluation of cell cycle progression, cell death and ROS release. The comparison between these three materials has not been reported before in literature to the best of our knowledge.

\section{MATERIALS AND METHODS}

\section{Materials}

This study comprised four groups each group made up of 7 wells of Normal Fibroblast cell line (WI-38) designated as follows:

$\begin{array}{ll}\text { Group I } & \text { Fibroblast (control) } \\ \text { Group II } & \text { Fibroblast+ PMMA } \\ \text { Group III } & \text { Fibroblast+ ACETAL } \\ \text { Group IV } & \text { Fibroblast+ PEEK }\end{array}$

\section{Methods}

\section{Cell line}

Human lung fibroblasts (WI-38) derived from embryonic normal human lung tissue. They are adherent and diploid cell lines of the American Type Culture Collection. ATCC \# CCL-75, that were obtained from VACSERA-EGYPT. The cells were cultured using DMEM (Invitrogen/ Life Technologies) supplemented with $10 \%$ FBS (Hyclone), $10 \mathrm{ug} / \mathrm{ml}$ of insulin (Sigma $\left.{ }^{\circledR}\right)$, and 1\% penicillin-streptomycin. All the additional chemicals and reagents were from Sigma ${ }^{\circledR}$, or Invitrogen ${ }^{\circledR}$. Plate cells density $1.2-1.8 \times 10,000$ cells/well, in a volume of $100 \mu 1$ complete growth medium.

\section{Digital designing of denture base samples}

Using blender software, a cylindrical mesh was designed in $5 \mathrm{~mm}$ diameter with $1 \mathrm{~mm}$ thickness and then exported in the form of S.T.L (standard tessellation language) file.

\section{Preparation of PMMA samples}

Seven designed samples were printed in castable resin, applicable to 3D printer Phrozen Shuffle, $500 \mathrm{~g}$, Taiwan) with the required dimensions using 3D printing technology with the available Dental 3D printer (Phrozen Shuffle 2018 Resin 3D Printer, XY Resolution: $47 \mu \mathrm{m}, \mathrm{Z}$ Resolution: $10 \mu \mathrm{m}$, Printing Speed: $30 \mathrm{~mm}$ per hour, Hsinchu City 30091, Taiwan) then the samples were flasked in to Heat-polymerized polymethyl methacrylate (PMMA) (Acrostone, Anglo- Egyptian Company. Hegaz, Cairo, Egypt) The preparation of specimens was conducted in Laboratory of Prosthodontic Department, Faculty of Dentistry, Future University in Egypt. following manufacturer instructions.

Following preparation, the specimens were left at $37^{\circ} \mathrm{C}$ in distilled water for $24 \mathrm{~h}$.

\section{Preparation of ACETAL Samples}

Seven designed samples were milled in to ACETAL by (arum 450 milling machine)

\section{Preparation of PEEK Samples}

Seven designed samples were milled in to PEEK (BIO HPP) by (arum 450 milling machine).

Each group comprised seven wells each well cultured with the tested material (direct contact method) and evaluated after 96 hours of culturing for groups II, III and IV while group I cells were cultured for 96 hours on their own. Samples used for evaluation in each group were made immediately before each experiment to avoid possible changes resulting from material aging. Prior to testing, the discs were cleansed ultrasonically in distilled water for $20 \mathrm{~min}$ and exposed to ultraviolet light for another 20 min to kill any microorganisms that may have caused contamination during fabrication. The groups were tested after 4 days of culturing with the tested material (and the same for the control group). 


\section{Human Reactive Oxygen Species (ROS) Elisa kit} (Amsbio)

ROS ELISA kit (Catalogue Number: AMS. E01R0021) applies the competitive enzyme immunoassay technique employing a monoclonal antiROS antibody and an ROS-HRP conjugate. The assay sample and buffer were incubated together with ROS-HRP conjugate in pre-coated plate for one hour. After the incubation period, wells were decanted and washed five times. Wells are then incubated with a substrate for HRP enzyme. The product of the enzyme-substrate reaction forms a blue colored complex. Finally, a stop solution was added to stop the reaction, which then turned the solution yellow. The intensity of color was measured spectro-photometrically at $450 \mathrm{~nm}$ in a microplate reader. The intensity of the color was inversely proportional to the ROS concentration since ROS.

\section{Flow cytometry}

\section{Cell Cycle Analysis using Flow cytometry}

The effect of the different denture base materials were tested through cell cycle analysis using the flow cytometry kit (BioVision ${ }^{\circledR}$ ). Cells were incubated, trypsinized and rinsed with PBS then suspended in $75 \%$ ice cold ethanol. Samples were stained using staining solution containing $50 \mu \mathrm{g} / \mathrm{mL}$ PI, $100 \mu \mathrm{g} /$ $\mathrm{mL}$ RNase and $0.1 \%$ Triton X-100. Cell cycle phase was determined by the DNA content.

\section{Apoptosis assessment}

For detection of apoptotic cells, Annexin V Apoptosis Detection Kit was used (Propidium Iodide (PI) ab139418) (BioVision $\left.{ }^{\circledR}\right)$. Cells were washed with cold PBS and the pellet was re-suspended in $100 \mu \mathrm{L}$ Annexin V Binding buffer. After mixing, $5 \mu \mathrm{L}$ of Annexin V-FITC and $5 \mu \mathrm{L}$ of propidium iodide were added. Each sample was then incubated for $15 \mathrm{~min}$ in the dark at room temperature. The samples were afterwards centrifuged and resuspended in $500 \mu \mathrm{L}$ of cell wash solution and analyzed, using FITC signal detector (usually FL1) and PI staining by the phycoerythrin emission signal detector.

\section{Statistical analysis}

Recorded data were analyzed using the statistical package for social sciences, version 20.0 (SPSS Inc., Chicago, Illinois, USA). Quantitative data were expressed as mean \pm standard deviation (SD). Qualitative data were expressed as frequency and percentage. A one-way analysis of variance (ANOVA) was used for comparing means among all groups, followed by pairwise analysis using Bonferroni test. In addition, the correlation coefficient tests were performed.

\section{RESULTS}

\section{Flow cytometry results}

The results of this study showed that highest mean values of total cell death, ROS levels and cell cycle arrest in the $\mathrm{G} 2 / \mathrm{M}$ phase of the cell cycle was noted in group II (PMMA/WI38). On performing ANOVA it was found that, there are significant differences among the studied groups and using Pairwise analysis using Bonferroni Method, significant differences between all groups were detected except for the $\mathrm{S}$ phase of the cell cycle where there appeared to be an insignificant difference between the control and peek groups (table 1, figure 1 and 2).

On performing Pearson's Correlation test ( $\mathrm{r}$ test) it was observed that ROS levels correlated positively with total cell death and G2/M arrest. On the other hand, it correlated negatively with all the other parameters (G0/G1 and S) (table 2). 
TABLE (1) Comparison between study groups as regards the mean value of Total Cell Deaths, ROS, G0/ G1, S phase and G2/M

\begin{tabular}{|c|c|c|c|c|c|c|c|c|c|c|}
\hline \multirow[b]{2}{*}{ Groups } & \multicolumn{2}{|c|}{ Total cell death } & \multicolumn{2}{|c|}{ ROS } & \multicolumn{2}{|c|}{ G0/G1 } & \multicolumn{2}{|c|}{ S phase } & \multicolumn{2}{|c|}{ G2/M } \\
\hline & $\begin{array}{l}\text { Mean } \\
\text { value }\end{array}$ & $\begin{array}{c} \pm \\
\text { SD }\end{array}$ & $\begin{array}{l}\text { Mean } \\
\text { value }\end{array}$ & $\pm \mathrm{SD}$ & $\begin{array}{l}\text { Mean } \\
\text { value }\end{array}$ & $\pm \mathrm{SD}$ & $\begin{array}{l}\text { Mean } \\
\text { value }\end{array}$ & $\pm \mathrm{SD}$ & $\begin{array}{l}\text { Mean } \\
\text { value }\end{array}$ & $\pm \mathrm{SD}$ \\
\hline Control.WI38 a & 1.507 & 0.006 & 34.710 & 0.095 & 58.970 & 0.061 & 37.103 & 0.263 & 3.680 & 0.010 \\
\hline PMMA/WI38 & 8.487 & 0.012 & 68.680 & 0.010 & 47.963 & 1.146 & 31.917 & 0.0153 & 19.430 & 0.010 \\
\hline ACETAL/WI38 ${ }^{\mathrm{c}}$ & 4.700 & 0.010 & 55.203 & 0.015 & 55.377 & 0.021 & 35.470 & 0.010 & 9.140 & 0.010 \\
\hline PEEK /WI38 d & 4.020 & 0.010 & 47.533 & 0.016 & 51.160 & 0.208 & 36.750 & 0.010 & 12.220 & 0.010 \\
\hline $\begin{array}{l}\text { ANOVA } \\
\text { P value }\end{array}$ & \multicolumn{2}{|c|}{$\begin{array}{c}<0.001 \text { highly } \\
\text { significant }\end{array}$} & \multicolumn{2}{|c|}{$\begin{array}{c}<0.001 \text { highly } \\
\text { significant }\end{array}$} & \multicolumn{2}{|c|}{$\begin{array}{c}<0.001 \text { highly } \\
\text { significant }\end{array}$} & \multicolumn{2}{|c|}{$\begin{array}{c}<0.001 \text { highly } \\
\text { significant }\end{array}$} & \multicolumn{2}{|c|}{$\begin{array}{c}<0.001 \text { highly } \\
\text { significant }\end{array}$} \\
\hline
\end{tabular}

N.B: For Post Hoc (Pairwise analysis using Bonferroni Method):

a Significant $(p<0.001)$ with each of the other groups (ACETAL/WI38,PMMA/WI38, PPEEK/WI38) for all groups except with group P.P/WI38, P=0.67) For $S$ is Insignificant

b Significant $(p<0.001)$ with each of the other groups (Control.WI38,ACETAL/WI38, PEEK/WI38)

c Significant ( $p<0.001$ ) with each of the other groups (Control.WI38, PMMA/WI38, PEEK/WI38)

d Significant $(p<0.001)$ with each of the other groups (Control.WI38, PMMA/WI38,PEEK/WI38)

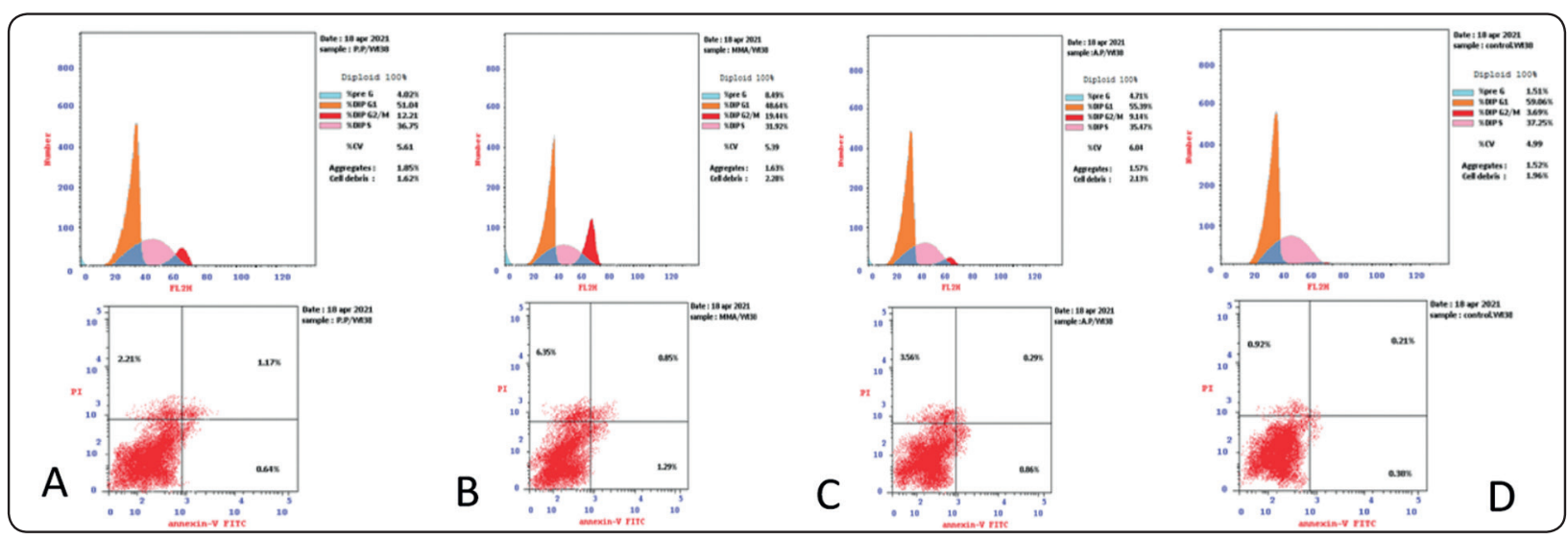

Fig. (1) Flow cytometric analysis of the cellular uptake Comparative flow cytometric dot quadrant plots of Annexin-V/PI (lower diagrams) A: Group I(control), B: Group II (PMMA), C: group III (Acetal), D: group IV (PEEK). 
TABLE (2): Correlation Matrix for study parameters using Pearson Correlation test ( $r$ test)

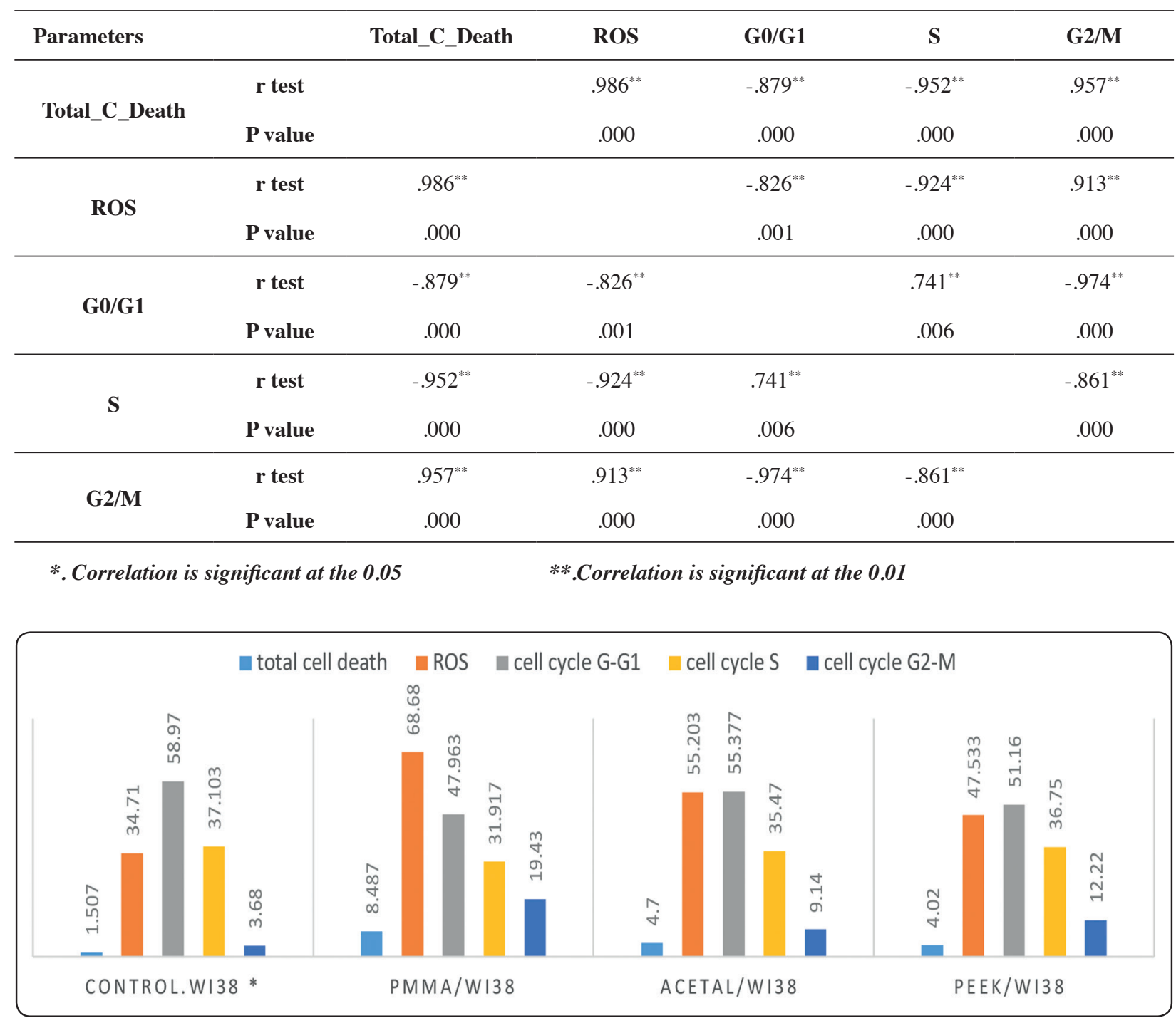

Fig. (2): Column chart showing the mean values of cell death, ROS, and cell cycle phases among the studied groups.

\section{DISCUSSION}

Removable prosthesis wearers are not all elderly patients ${ }^{(17)}$, on the contrary, a large body of users are young patients like those suffering from clefts, missing teeth, besides which there is a category of patients of diverse age groups of those who underwent cancer treatment and might require obturators. ${ }^{(18)}$. Denture-base materials come into direct contact with oral mucosa and can cause adverse reactions on oral mucosa and submucosa ${ }^{(3,19)}$. Removable prosthesis are worn by users for the majority of their day and thus the biocompatibility of these materials is of utmost importance especially when users are young in age that will utilize these devices for years and years to come.

The rationale behind the study being that even though PMMA is the cheapest and most widely used denture base material however, several studies 
documented that it exhibited deleterious influence on keratinocytes ${ }^{(20)}$ and fibroblasts in vitro and the oral tissues in vivo ${ }^{(21)}$. On the other hand, AC is preferred by many dentists due to its superior mechanical, physical and biological properties however, still PMMA poses as the cheaper treatment option. PEEK appears to be ideal in every way, nevertheless, its high price makes its routine selection problematic.

This work was performed to evaluate the cytotoxicity of these materials and whether the differences in cytotoxicity between these materials is significant enough to oblige dentists to use a more expensive material, as human health is the single most important factor to consider.

The cells of choice for this study were fibroblasts as they represent the most abundant cells of connective tissue in not only in the oral cavity but all over the body. In times of insult fibroblasts initially act in repairing the problem however in cases of long term irritation or pathological incidences fibroblasts the long-term dysregulated production of extracellular matrix eventually causes disfigurement or dysfunction ${ }^{(7)}$. They are as well proliferating cells and hence provide a reasonable model to study the effect of the evaluated denture base materials on cell cycle and cell death. WI-38 recommended by the ISO10993-5:2009 standard as cell line models for cytotoxicity testing ${ }^{(22)}$. To the best of our knowledge this is the first study to compare the effect of these three denture base materials on a non- animal cell line.

The PMMA group in this study exhibited the significantly higher ROS levels compared to all the other groups, which also positively correlated with a significantly higher number of cells in the G2/M phase of the cell cycle, which may indicate sever damage to the cells and is consistent with concomitant increase in cell death rate for the same group. These results were similar to those obtained by Yu Zhang et al, 2019, Who stated that PMMA resulted in increased apoptosis and they attributed to the oxidative stress caused by ROS release ${ }^{(23)}$. However, the results of the current study also showed that there is a significant increase in cellular apoptosis and ROS in the AC group compared to the control group, this may be explained by the fact that AC may have leached some residual formaldehyde which resulted in oxidative stress followed by a prominent increase in apoptotic cells compared to the control group. A significantly higher number of cells were in the G/G1 phase of the cell cycle (significantly higher than all the other test groups but not higher than the control group) this may be due to the fact that aberrations in cell growth and nutrients caused the cells to halt in this checkpoint, prolonged arrest may push the cells into senescence The reason why this seen more in the AC group may be due to the fact that the stress is not high enough to cause cell death ${ }^{(8)}$.

Last but not least PEEK exhibited an insignificant difference between cells in the $\mathrm{S}$ phase of the cell cycle and the control group, which may signify that the stress levels were low and thus the number of proliferating cells in the PEEK group were similar to those of the control group.

It should be noted that there was still a significant rise in the levels of the ROS in the PEEK group over the control group, this may be explained merely by the mechanical stress caused by the physical presence of the tested specimen in direct contact with the fibroblasts. Cells constantly receive various tissue-associated physical forces including hydrostatic pressure, shear stress, compression and tension ${ }^{(24)}$. The YAP/TAZ pathway, is now identified as a key pathway that sense mechanical stimuli and relay the signals to control transcriptional programs for cell differentiation, proliferation, and transformation ${ }^{(25)}$. It should be noted that this mechanical stress variable will be present in all the tested groups but not the control group. 


\section{CONCLUSION}

From the result of this study, we conclude that PEEK showed significantly superior biocompatibility compared to ACETAL and PMMA, enough to justify its use as a denture base material in spite of its high price. Further studies are required in vivo to further validate the results of this study.

\section{REFERENCES}

1. Campbell SD, Cooper L, Craddock H, Hyde TP, Nattress B, Pavitt SH, et al. Removable partial dentures: The clinical need for innovation. J Prosthet Dent. 2017;118(3): 273-80.

2. Jaafar M. Review on poly-methyl methacrylate as denture base materials. Malaysian J Microsc. 2018;14(1).

3. Abdelhameed B, Abdullah E. Clinical and Microbiological Evaluation of the Effect of Heat Killed Lactobacillus Acidophilus and Garlic Extract on Candida Albicans in a Group of Elderly Denture Wearers. Egypt Dent J. 2021;67(2):1475-86.

4. Gautam R, Singh RD, Sharma VP, Siddhartha R, Chand P, Kumar R. Biocompatibility of polymethylmethacrylate resins used in dentistry. J Biomed Mater Res Part B Appl Biomater. 2012;100(5):1444-50.

5. Ansteinsson V, Kopperud HB, Morisbak E, Samuelsen JT. Cell toxicity of methacrylate monomers - The role of glutathione adduct formation. J Biomed Mater Res Part A An Off J Soc Biomater Japanese Soc Biomater Aust Soc Biomater Korean Soc Biomater. 2013;101(12):3504-10.

6. Pituru SM, Greabu M, Totan A, Imre M, Pantea M, Spinu $\mathrm{T}$, et al. A review on the biocompatibility of PMMA-based dental materials for interim prosthetic restorations with a glimpse into their modern manufacturing techniques. Materials (Basel). 2020;13(13):2894.

7. Obeid RF, Elsharkawy RT, El-kammar HA. Effect of Vitamin C Administration 24 Hours After 5-Fluorouracil Versus its Concomitant Administration on Cellular Proliferation, Cell Death and Lipid Peroxidation in WI-38 Human Fibroblast Cell Line. Egypt J Histol. 2020;

8. Redza-Dutordoir M, Averill-Bates DA. Activation of apoptosis signalling pathways by reactive oxygen species. Biochim Biophys Acta (BBA)-Molecular Cell Res. 2016;1863(12):2977-92.
9. Merlin JP, Rupasinghe HP, Dellaire G, Murphy K. Role of dietary antioxidants in p53-mediated cancer chemoprevention and tumor suppression. Oxid Med Cell Longev. $2021 ; 2021$.

10. Pan Z, Zhang X, Yu P, Chen X, Lu P, Li M, et al. Cinobufagin induces cell cycle arrest at the G2/M phase and promotes apoptosis in malignant melanoma cells. Front Oncol. 2019;9:853.

11. Saravi ME, Vojdani M, Bahrani F. Evaluation of cellular toxicity of three denture base acrylic resins. J Dent (Tehran). 2012;9(4): 180 .

12. Ata SO, Yavuzyılmaz H. In vitro comparison of the cytotoxicity of acetal resin, heat-polymerized resin, and autopolymerized resin as denture base materials. J Biomed Mater Res Part B Appl Biomater An Off J Soc Biomater Japanese Soc Biomater Aust Soc Biomater Korean Soc Biomater. 2009;91(2):905-9.

13. Alqurashi H, Khurshid Z, Syed AUY, Habib SR, Rokaya D, Zafar MS. Polyetherketoneketone (PEKK): An emerging biomaterial for oral implants and dental prostheses. $\mathrm{J}$ Adv Res. 2021;28:87-95.

14. Tekin S, Cangül S, Adıgüzel Ö, Değer Y. Areas for use of PEEK material in dentistry. Int Dent Res. 2018;8(2):84-92.

15. de Araújo Nobre M, Moura Guedes C, Almeida R, Silva A, Sereno N. Hybrid Polyetheretherketone (PEEK)-Acrylic Resin Prostheses and the All-on-4 Concept: A Full-Arch Implant-Supported Fixed Solution with 3 Years of FollowUp. J Clin Med. 2020;9(7):2187.

16. Li W, Zhou J, Xu Y. Study of the in vitro cytotoxicity testing of medical devices. Biomed reports. 2015;3(5):617-20.

17. Yen Y-Y, Lee H-E, Wu Y-M, Lan S-J, Wang W-C, Du J-K, et al. Impact of removable dentures on oral health-related quality of life among elderly adults in Taiwan. BMC Oral Health. 2015;15(1):1-12.

18. Goyal M, Chopra R, Bansal K, Marwaha M. Role of obturators and other feeding interventions in patients with cleft lip and palate: a review. Eur Arch Paediatr Dent. 2014;15(1):1-9.

19. Kostic M, Pejcic A, Igic M, Gligorijevic N. Adverse reactions to denture resin materials. Eur Rev Med Pharmacol Sci. 2017;21(23):5298-305.

20. Raszewski Z. Influence of polymerization method on the cytotoxicity of three different denture base acrylic resins polymerized in different methods. Saudi J Biol Sci. 2020;27(10):2612-6. 
21. Goiato MC, Freitas E, dos Santos D, de Medeiros R, Sonego M. Acrylic Resin Cytotoxicity for Denture Base-Literature Review. Adv Clin Exp Med Off organ Wroclaw Med Univ. 2015;24(4):679-86.

22. Souto-Lopes M, Azevedo Á, Teixeira A, Bastos-Aires D, Lordelo J, Pérez-Mongiovi D. Cytotoxicity of acrylic based resin compounds in a human gingival fibroblast cell line. Rev Port Estomatol Med Dentária e Cir Maxilofac. 2013;54(2):87-90.

23. Zhang Y, Xiao J, Yang H, Jiao Y, Cao W, Shi H, et al.
$\mathrm{N}$-Acetyl cysteine as a novel polymethyl methacrylate resin component: protection against cell apoptosis and genotoxicity. Oxid Med Cell Longev. 2019;2019.

24. Dolega ME, Delarue M, Ingremeau F, Prost J, Delon A, Cappello G. Cell-like pressure sensors reveal increase of mechanical stress towards the core of multicellular spheroids under compression. Nat Commun. 2017;8(1):1-9.

25. Cai X, Wang K-C, Meng Z. Mechanoregulation of YAP and TAZ in cellular homeostasis and disease progression. Front Cell Dev Biol. 2021;9. 